\title{
Plyometric basketball training
}

\author{
Ana Nikolic \\ Faculty of Sport and Physical Education, University of Nis, Nis, Serbia.
}

\begin{abstract}
Plyometric basketball training represents a widely used training method whose purpose is to resist the gravity force, meaning jump height improvement, better start acceleration, short section sprint, and direction change movement. The aim of this work was to analyze former plyometric basketball training researches, as well as to consolidate conclusions relevant to established work object analysis. This work covers 22 surveys published during a period from 2008 till 2018, which are shown in a chronological order and analyzed thoroughly. Obtained results suggest that fully planned and performed plyometric training within a defined time period has statistically significant positive effects on basketball explosive capacities development.
\end{abstract}

Keywords. Basketball, development, explosive capacity, plyometric training, motoric skills.

\section{Introduction}

$\mathrm{B}$ asketball is a very complex activity, where being successful depends on numerous anthropometric and motoric skills. Basic characteristic of basketball activities are quick direction change movements, as well as those of motoric structure movement intensity with and without a ball. Ability of quick activity beginning, movement stereotype reorganization and precise movements in relatively small spaces with space and time limitations represent basketball player activity characteristics and are directly connected to ability of quality performance of speed-explosive capacities. Speed, explosivity and agility represent abilities of analogue ways of expression, making it possible to connect them in the same context of basketball players practice and training (Trunic \& Mladenovic, 2014).

As one of the most interesting training methods of the 20th century, plyometric training appeared in Zaciorski's book in 1966. The term "plyometry" can be connected to various terms such as stress training, speed capacity, jump and elastic reactivity training (Radcliffe \& Farentinos, 2003). There have been many plyometry definitions given by different authors. It is one of the best methods for development of different types of explosive capacities, and can be described as any training with eccentric-concentric muscle activity (Canaki \& Birkic, 2009).

Plyometric training is about using gravity force for quick muscle extension while touching back the ground within jumping, in order to create potential elastic energy for more efficient jump off the ground concentric phase realization (Radovanovic \& Ignjatovic, 2009). Plyometry refers to exercises designed for better muscle capacities by jumping (De Villarreal et al., 2009).

Plyometric exercises are those exercises whose purpose is to connect force and speed of movement in order to achieve explosive-reactive movement, often defined as capacity (Pavlek, 2009; Vrcic, 2009).

Basic plyometric method means are vertical, horizontal and deep jumps. Such jumps include countermovement jump (CMJ), drop jump (DJ) and squat jump (SJ), which represent the most used jumps within plyometric training (Brankovic et al., 2008).

Plyometric training consists of exercises which can be performed with or without external burden, while the results obtained may vary depending on training, sex, age, sport activity, as well as on knowledge of plyometric exercice practice (Arazi \& Asadi, 2011).

Plyometric training represents highly intensive training method which should be applied and dosed adequately in order to avoid unpleasant consequences like injuries. While planning and 
programming the training including plyometric exercises it is necessary to pay attention to sex, age, as well as morphological structure of an athlete (Stemm \& Jacobson, 2007). Plyometric training is designed for those athletes with long term capacity training. Muscles have to be strong enough to endure due to big force production during plyometric exercises (Radovanovic \& Ignjatovic, 2009).

\section{Methods}

Descriptive method and theoretical analysis were used in this research. For searching former surveys on plyometric basketball training next electronic data bases were used: Google Scholar, SCIndeks, MEDLINE, SPORTDiscus, PubMed and Web of Science. While searching these data bases next key words were used: basketball, development, explosive capacity, plyometric training, and motoric skills. The search covered publications from 2008 till 2018.

Table 1

Review of collected and analyzed studies.

\begin{tabular}{|c|c|c|c|c|c|c|c|}
\hline \multirow[b]{2}{*}{ References } & \multicolumn{5}{|c|}{ Sample of respondents } & \multicolumn{2}{|c|}{ Experimental treatment } \\
\hline & $\mathrm{n}$ & Age & Sex & Time period & Groups & $\begin{array}{l}\text { Measured } \\
\text { parameters }\end{array}$ & Results \\
\hline $\begin{array}{l}\text { Boraczyñski \& } \\
\text { Urnia, } 2008\end{array}$ & 14 & $20.3 \pm 1.9$ & $\mathrm{M}$ & $\begin{array}{c}8 \text { weeks }(3 x \text { a } \\
\text { week })\end{array}$ & $\mathrm{P}$ & $\begin{array}{l}\text { Low limbs } \\
\text { explosive capacity }\end{array}$ & $\begin{array}{l}\text { Progress in measured } \\
\text { parameters }\end{array}$ \\
\hline Shaji \& Isha, 2009 & 45 & $18-25$ & $\mathrm{M}$ & $\begin{array}{c}4 \text { weeks }(2 \mathrm{x} \text { a } \\
\text { week) }\end{array}$ & $\begin{array}{l}\text { Di; P; } \\
\text { DiP }\end{array}$ & $\begin{array}{l}\text { Vertical jump } \\
\text { height }\end{array}$ & $\begin{array}{l}\text { Improvement in vertical } \\
\text { jump height in all three } \\
\text { groups }\end{array}$ \\
\hline Kukrić et al., 2010 & 20 & Juniors & $\mathrm{M}$ & $\begin{array}{l}10 \text { weeks }(2 x \\
\text { a week) }\end{array}$ & $\mathrm{P} ; \mathrm{K}$ & $\begin{array}{c}\text { Leg explosive } \\
\text { capacity (CMJ and } \\
\text { SJ) }\end{array}$ & $\begin{array}{l}\text { Improvement in } \mathrm{CMJ} \text { and } \\
\text { SJ jumps in } \mathrm{P} \text { group }\end{array}$ \\
\hline Shallaby, 2010 & 20 & 16 & M & $\begin{array}{l}12 \text { weeks ( } 3 x \\
\text { a week/ } \\
\text { 120minutes) }\end{array}$ & $\mathrm{P} ; \mathrm{K}$ & $\begin{array}{l}\text { Vertical jump } \\
\text { height }\end{array}$ & $\begin{array}{l}\text { P group progressed more } \\
\text { than } \mathrm{K} \text { group }\end{array}$ \\
\hline $\begin{array}{l}\text { Draganović \& } \\
\text { Marković, } 2011\end{array}$ & 23 & Juniors & $\mathrm{M}$ & $\begin{array}{c}6 \text { weeks }(2 x \text { a } \\
\text { week })\end{array}$ & $\mathrm{P} ; \mathrm{K}$ & $\begin{array}{l}\text { Vertical jump } \\
\text { height }\end{array}$ & $\begin{array}{l}\text { Statistically significant } \\
\text { improvement of P group } \\
\text { compared to K group }\end{array}$ \\
\hline $\begin{array}{l}\text { Adorable et al., } \\
2011\end{array}$ & 9 & Students & $\mathrm{M}$ & 10 weeks & $\mathrm{P}$ & $\begin{array}{l}\text { Vertical jump } \\
\text { height }\end{array}$ & $\begin{array}{l}\text { Statistically significant } \\
\text { improvement of the } \\
\text { measured parametre }\end{array}$ \\
\hline $\begin{array}{l}\text { Sharma \& } \\
\text { Multani, } 2012\end{array}$ & 40 & / & M & 4 weeks & $\mathrm{P} ; \mathrm{K}$ & $\begin{array}{c}\text { Low limbs } \\
\text { explosive capacity }\end{array}$ & $\begin{array}{c}\text { Significant improvement } \\
\text { of P group compared to } \mathrm{K} \\
\text { group }\end{array}$ \\
\hline $\begin{array}{l}\text { Asadi \& Arazi, } \\
2012\end{array}$ & 16 & $19-20$ & M & $\begin{array}{c}6 \text { weeks }(2 \mathrm{x} \text { a } \\
\text { week })\end{array}$ & $\mathrm{P} ; \mathrm{K}$ & $\begin{array}{l}\text { Low limbs } \\
\text { explosive capacity, } \\
\text { Vertical jump } \\
\text { height }\end{array}$ & $\begin{array}{l}\text { Statistically significant } \\
\text { improvement of Low } \\
\text { limbs explosive capacity in } \\
\text { P group }\end{array}$ \\
\hline
\end{tabular}

Surveys which were up to given criteria were analyzed and presented based on these parameters: reference (names of authors and publication year), sample of respondents (number, age and sex of the respondent), experimental treatment (time period of experimental treatment, groups and analyzed parameters), survey results.

\section{Results}

Draganovic \& Markovic (2011) came to a conclusion that plyometric method improves vertical jump height at junior basketball players. Similar results were obtained by Kukric et al. (2010). Namely, they discovered that 10 week plyometric training (twice a week), where number of exercises and jumps is higher each week with three minute breaks between series, and five minute breaks between exercises, brings to higher vertical jump at junior basketball players. 


\begin{tabular}{|c|c|c|c|c|c|c|c|}
\hline \multicolumn{8}{|c|}{ Table 1. (Continued) } \\
\hline Bavli, 2012a & 91 & $15-17$ & $\mathrm{M} / \mathrm{F}$ & $\begin{array}{c}12 \text { weeks ( } 3 x \\
\text { a week) }\end{array}$ & $\mathrm{P} ; \mathrm{K} ; \mathrm{Pv}$ & $\begin{array}{l}\text { Vertical jump } \\
\text { height }\end{array}$ & $\begin{array}{l}\text { Improvement of vertical } \\
\text { jump height in } \mathrm{P} \text { and } \mathrm{Pv} \\
\text { groups }\end{array}$ \\
\hline Bavli, 2012b & 24 & $20.7 \pm 2.6$ & M & 6 weeks & $\mathrm{P} ; \mathrm{K}$ & $\begin{array}{l}\text { Vertical jump } \\
\text { height }\end{array}$ & $\begin{array}{l}\text { P group progress in } \\
\text { measured parametre }\end{array}$ \\
\hline Arazi et al., 2012 & 18 & $18.81 \pm 1.46$ & M & $\begin{array}{l}8 \text { weeks }(3 \mathrm{x} \text { a } \\
\text { week } / 40 \mathrm{~min})\end{array}$ & $\begin{array}{l}\mathrm{P} ; \mathrm{Pv} ; \\
\mathrm{K}\end{array}$ & $\begin{array}{l}\text { Vertical jump } \\
\text { height }\end{array}$ & $\begin{array}{l}\text { Improvement of vertical } \\
\text { jump height in } \mathrm{P} \text { and } \mathrm{Pv} \\
\text { groups }\end{array}$ \\
\hline $\begin{array}{l}\text { Komal \& Singh, } \\
2013\end{array}$ & 45 & $16-18$ & $\mathrm{~F}$ & 8 weeks & $\mathrm{P} ; \mathrm{K} ; \mathrm{T}$ & $\begin{array}{l}\text { Vertical jump } \\
\text { height }\end{array}$ & $\begin{array}{c}\text { Statistically significant } \\
\text { improvement in } \mathrm{P} \text { and } \mathrm{T} \\
\text { groups compared to } \mathrm{K} \\
\text { group }\end{array}$ \\
\hline Zhang, 2013 & 17 & $18-24$ & M & $\begin{array}{l}4 \text { weeks ( } 3 \text { x a } \\
\text { week/ } \\
60 \text { minutes) }\end{array}$ & $\mathrm{P}$ & $\begin{array}{l}\text { Vertical jump } \\
\text { height with left leg, } \\
\text { right leg and both } \\
\text { leg jump }\end{array}$ & $\begin{array}{l}\text { Improvement in all } \\
\text { measured parameters, } \\
\text { except for both leg jump }\end{array}$ \\
\hline Asadi, 2013 & 20 & $20.1 \pm 1.3$ & M & $\begin{array}{c}6 \text { weeks }(2 \mathrm{x} \text { a } \\
\text { week) }\end{array}$ & $\mathrm{P} ; \mathrm{K}$ & $\begin{array}{l}\text { Vertical jump } \\
\text { height long jump } \\
\text { length }\end{array}$ & $\begin{array}{l}\text { P group progressed in } \\
\text { both measured parameters }\end{array}$ \\
\hline $\begin{array}{l}\text { Lehnert et al., } \\
2013\end{array}$ & 12 & $24.36 \pm 3.9$ & M & $\begin{array}{c}4 \text { weeks }(2 \mathrm{x} \text { a } \\
\text { week })+ \\
2 \text { weeks }(4 \mathrm{x} \text { a } \\
\text { week) }\end{array}$ & $\mathrm{P}$ & $\begin{array}{l}\text { Low limbs } \\
\text { explosive capacity }\end{array}$ & $\begin{array}{c}\text { Statistically significant } \\
\text { improvement was not } \\
\text { noticed }\end{array}$ \\
\hline Attene et al., 2014 & 36 & $14.9 \pm 0.9$ & $\mathrm{~F}$ & 6 weeks & $\mathrm{P} ; \mathrm{K}$ & $\begin{array}{l}\text { Vertical jump } \\
\text { height }\end{array}$ & $\begin{array}{l}\text { Statistically significant } \\
\text { improvement in Vertical } \\
\text { jump height in both } \\
\text { groups }\end{array}$ \\
\hline $\begin{array}{l}\text { Morsal et al., } \\
2014\end{array}$ & 30 & $24-30$ & M & $\begin{array}{c}6 \text { weeks }(3 \times \text { a } \\
\text { week) }\end{array}$ & $\mathrm{P} ; \mathrm{K}$ & $\begin{array}{l}\text { Low limbs } \\
\text { explosive capacity }\end{array}$ & $\begin{array}{l}\text { Low limbs explosive } \\
\text { capacity improvement in } \mathrm{P} \\
\text { group }\end{array}$ \\
\hline Zribi et al., 2014 & 51 & l & M & 9 weeks & $\mathrm{P} ; \mathrm{K}$ & $\begin{array}{l}\text { Low limbs } \\
\text { explosive capacity }\end{array}$ & $\begin{array}{l}\text { Statistically significant } \\
\text { improvement in P group }\end{array}$ \\
\hline $\begin{array}{l}\text { Gottlieb et al., } \\
2014\end{array}$ & 19 & $16.3 \pm 0.5$ & M & $\begin{array}{c}8 \text { weeks }(2 \mathrm{x} \text { a } \\
\text { week) }\end{array}$ & $\mathrm{P} ; \mathrm{Sp}$ & $\begin{array}{l}\text { Vertical jump } \\
\text { height }\end{array}$ & $\begin{array}{l}\text { P group progressed in } \\
\text { measured parameter }\end{array}$ \\
\hline $\begin{array}{l}\text { Ramateerth \& } \\
\text { Kannur, } 2014\end{array}$ & 21 & $12-13$ & M & $\begin{array}{l}6 \text { weeks }(2 \text { x a } \\
\text { week/ } 90 \\
\text { minutes })\end{array}$ & S; Ps & $\begin{array}{l}\text { Vertical jump } \\
\text { height, long jump } \\
\text { and ball throw }\end{array}$ & $\begin{array}{c}\text { Statistically significant } \\
\text { improvement in Ps group } \\
\text { in all three measured } \\
\text { parameters }\end{array}$ \\
\hline Benis et al., 2015 & 24 & $15.9 \pm 0.8$ & $\mathrm{~F}$ & 8 weeks & $\mathrm{K} ; \mathrm{P}$ & $\begin{array}{l}\text { Vertical jump } \\
\text { height }\end{array}$ & $\begin{array}{l}\text { Improvement of vertical } \\
\text { jump height in } \mathrm{P}\end{array}$ \\
\hline $\begin{array}{l}\text { Khazai } \\
\text { \&Hematfar, } 2015 .\end{array}$ & 16 & $11-12$ & $\mathrm{~F}$ & $\begin{array}{c}4 \text { weeks ( } 3 \mathrm{x} \text { a } \\
\text { week/ } 60 \\
\text { minutes) }\end{array}$ & $\mathrm{K} ; \mathrm{P}$ & $\begin{array}{l}\text { Vertical jump } \\
\text { height }\end{array}$ & $\begin{array}{l}\text { Statistically significant } \\
\text { improvement in P group } \\
\text { in measured parameter }\end{array}$ \\
\hline
\end{tabular}

Legend; P-plyometry program group; K- control group; Ps - combination of plyometry and strength training group (no weights); Di dynamic extension group; DiP - combination of dynamic extension and plyometry exercises group; Pv- water plyometry training group; Ps- sagittal plane plyometry jumps group; CMJ Countermovement Jump -; SJ Squat Jump.

Shaji \& Isha (2009) came to a conclusion that plyometric training program within four weeks (twice a week) brings to statistically significant improvement of vertical jump height at basketball players, with $3,6 \mathrm{~cm}$ average $(7,9 \%)$. Similar results were obtained by Sharma \& Multani (2012) and Khazai \& Hematfar (2015) in female basketball players.

As Asadi \& Arazi (2012) discovered, a six week plyometric training (twice a week) brings to 
statistically significant vertical jump height improvement with $23 \%$ average at male basketball players, while Attene at al. (2014) came to a conclusion that six week plyometric training brings to $15,4 \%$ better vertical jump height at female basketball players. Similar results were obtained by Draganovic \& Markovic (2011), who, based on the results obtained in their research, claim that a six week plyometric training brings to better vertical jump height for $6 \mathrm{~cm}$ at junior players. This fact suggests that even though a four week plyometric training brings to a vertical jump height improvement, better results can be obtained by this method within a longer time period.

Drop jump, drop jump to standing, long jump and squat jump as plyometric exercises for basketball players jumping abilities development were used in Asadi \& Arazi research (2012).

Some studies have shown that plyometric training does not have to last long to have positive effects on explosive capacity development at basketball players. Based on his own research, Bavli (2012) came to a conclusion that a six week plyometric training (twice a week, 20 to 30 minutes each) brings to a significant improvement of vertical jump height at basketball players.

Table 1 shows that a plyometric training lasting between six and ten weeks improves basketball players' explosive capacity, based on some researches. Besides having positive effects on explosive capacity development using experimental training with plyometric exercises, results obtained show that a plyometric training lasting from six to twelve weeks also has a positive effect on such capacity development at female basketball players.

The only research included in this work where plyometric training did not bring to any significant vertical jump height improvement was done by Lehnert et al. (2013). Their research respondents were of $24.36 \pm 3.9$ average age, and experimental program lasted six weeks (twice a week from the first to the fourth week and four times a week during the fifth and the sixth week). In the last two weeks lower limb plyometric exercises were combined with upper limb exercises with a burden during one training and vice verso. Number of jumps increased gradually during the program. Besides plyometric program basketball players also had to do their condition trainings including speed and aerobic durability exercises, as well as burden trainings.
One of interesting methods of plyometric training which was proved to have positive effects on basketball players explosive capacities by Arazi et al. (2012) is a water plyometric training whic lessens chances for injuries, besides being very efficient.

\section{Discussion}

Being a sport activity with plenty of explosive movements like short sprints, quick stops and accelerations, direction movement changes, different types of jumps, throwing and passing the ball, basketball suggests the significance of basketball players' explosive capacities for achieving maximum results. One of the most used methods for these capacities improvement during the past decades has been plyometric training. Applying adequate plyometric exercises, their correct dosing, insisting on correct performance and adequate break between series and repetitions can undoubtedly bring to basketball players explosive capacity improvement, which represents one of the conditions for being successful at this collective sport. There are many proofs to these claims - many researches have been done on the subject of plyometric basketball training. Results of all the studies included in this work except one, have undoubtedly suggested that experimental treatment based on plyometric exercises within a limited time period brings to statistically significant improvement in studied parameters.

\section{References}

Adorable L, Caparino CA, Abbu CC. The effect of plyometric training on the vertical leap of university varsity basketball players. In. A. Wicker (Ed), 7th EFSMA - European Congress of Sports Medicine, 3rd Central European Congress of Physical Medicine and Rehabilitation (pp.44-45). Salzburg: Austrian Society of Physical Medicine and Rehabilitation, 2011.

Arazi H, Asadi A. The effect of aquatic and land plyometric training on strength, sprint, and balance in young basketball players. Journal of Human Sports \& Exercise, 2011; 6 (1): 101-111.

Arazi H, Coetzee B, Asadi A. Comparative effect of landand aquatic-based plyometric training on jumping ability and agility of young basketball players. South African Journal for Research in Sport, Physical Education and Recreation, 2012; 34(2): 1-4.

Asadi A. Effects of in-season plyometric training on sprint and balance performance in basketball players. Sport Science, 2013b; 6(1): 24-27. 
Attene G, Iuliano E, Di Cagno A, Calcagno G, Moalla W, Aquino G, Padulo J. Improving neuro-muscular performance in young basketball players: plyometric vs. technique training. J Sport Med Phys Fit, 2014; 55(1-2): 1-8.

Bavli O. Investigation the effects of combined plyometrics with basketball training on some biomotorical performance. Pamukkale Journal of Sport Sciences, 2012a; 3(2): 90-100.

Bavli O. Comparison the effect of water plyometrics and land plyometrics on body mass index and biomotorical variables of adolescent basketball players. International Journal of Sport and Exercise Science, 2012b; 4(1): 11-14.

Benis R, Rossi R, Russo L, La Torre A. The effects of 8 weeks of plyometric training on sprint and jump performance in female high school basketball players. In. S. Hedenborg (Ed), 20th Annual Congress of the European College of Sport Science, Sustainable Sport (pp. 332-345). Malmö: Malmö University, Lund University \& Copenhagen University, 2015.

Boraczyñski T, Urnia J. The effect of plyometric training on strength-speed abilities of basketball players. Research Yearbook, 2008; 14(1): 14-19.

Draganović A, Marković S. Influence of plyometric training on the development of leg explosive strength. Proceedings, 2011; 3: 183-188.

deVillarreal ESS, Kellis E, Kraemer WJ, Izquierdo M. Determining variables of plyometric training for improving vertical jump height performance: a meta-analysis. J Strength Cond Res, 2009; 23(2): 495506.

Gottlieb R, Eliakim A, Shalom A, Dello-Iacono A, Meckel $Y$. Improving anaerobic fitness in young basketball players: plyometric vs. specific sprint training. J Athl Enhanc, 2014; 3(3): 1-6.

Jamurtas AZ, Fatouros IG, Buckenmeyer P, Kokkinidis E, Taxildaris K, Kambas A, Kyriazis G. Effects of plyometric exercise on muscle soreness and plasma creatine kinase levels and its comparison with eccentric and concentric exercise. J Strength Cond Res, 2000; 14(1): 68-74.

Komal, Singh N. Comparative effect of plyometric training and resistance training on selected fitness variables among national level female basketball players. Asian Resonance, 2013; 2(4): 271-275.

Khazai L, Hematfar A. Comparison of two short-term of weight and plyometric training on vertical jump of young female basketball players. Asian Journal of Multidisciplinary Studies, 2015; 3(1): 213-215.

Lehnert M, Hůlka K, Malý T, Fohler J, Zahálka F. The effects of a 6 week plyometric training programme on explosive strength and agility in professional basketball players. Acta Gymnica, 2013; 43(4): 7-15.

Morsal B, Shahnavazi A, Ahmadi A, Zamani N, Tayebisani M, Rohani A. Effects of polymeric training on explosive power in young male basketball. European Journal of Experimental Biology, 2014; 4(3): 437-439.

Radcliffe J, Farentinos R. Plyometric. Zagreb: Gopal, 2003.

Shaji J, Isha S. Comparative analysis of plyometric training program and dynamic stretching on vertical jump and agility in male collegiate basketball player. Al Ameen Journal of Medical Sciences, 2009; 2(1): 3646.

Shallaby HK. The effect of plyometric exercises use on the physical and skillful performance of basketball players. World Journal of Sport Sciences, 2010; 3(4): 316-324.

Sharma D, Multani NK. Effectiveness of plyometric training in the improvement of sports specific skills of basketball players. Indian J Physiother Occup Ther, 2012; 6(1): 77-82.

Stemm JD, Jacobson BH. (2007). Comparison of land-and aquatic-based plyometric training on vertical jump performance. J Strength Cond Res, 2007; 21(2): 568571.

Zhang X. Research of jumping ability and explosive power based on plyometric training. Lecture Notes in Electrical Engineering, 2013; 206: 427-433.

Zribi A, Zouch M, Chaari H, Bouajina E, Ben NH, Zaouali M, Tabka Z. Short-term lower-body plyometric training improves whole body BMC, bone metabolic markers, and physical fitness in early pubertal male basketball players. Pediatr Exerc Sci, 2014; 26(1): 22-32. 